\title{
Notes on the arthropod fauna of Salas $y$ Gómez island, Chile
}

\author{
Samantha N. Hershauer ${ }^{1}$, Sebastian Yancovic Pakarati ${ }^{2}$ and J. Judson Wynne ${ }^{1,3^{*}}$ (D)
}

\begin{abstract}
Background: Salas y Gómez is a small, volcanic island largely untouched by humans due to its diminutive size and remoteness. Since the waters surrounding Salas y Gómez were established as Motu Motiro Hiva Marine Park in 2010, marine investigations have been the primary research focus. Secondarily, nesting seabird communities have been censused since 2011.

Methods and findings: In 2016, terrestrial arthropods were sampled on the island. Two observers sampled two locations for $30 \mathrm{~min}$ per site. Fifteen morphospecies were identified including at least one likely undescribed species.

Conclusions: Our work represents the most comprehensive terrestrial arthropod inventory of Salas y Gómez island to date. We are hopeful the recommendations provided will spur additional research to both characterize the island's arthropod community, as well as identify species of management concern.
\end{abstract}

Keywords: Species inventory, Motu Motiro Hiva Marine park, Oceanic islands, Polynesia

\section{Background}

Prior to this study, our knowledge concerning the natural history of Salas y Gómez island was largely limited to the marine animals and pelagic bird rookeries. The marine ecosystem is characterized by high biodiversity including numerous endemic species $[1,2]$. More than $38 \%$ of fish species found in Salas y Gómez waters are considered endemic to the island [2]. While surveys to initially document seabirds occurred earlier on [3-5], annual pelagic bird surveys have been conducted since 2011 [6]. To date, at least at least 16 avian species nest on the island [3-6].

Given the importance of the marine ecosystem, the waters surrounding Salas y Gómez island were designated as a "Natural Sanctuary" in 1976 [8]. In 2010, the Chilean government established Motu Motiro Hiva Marine Park; at which time $150,000 \mathrm{~km}^{2}$ were designated a "no take zone" [9] (i.e., fishing and other resource extraction activities

\footnotetext{
* Correspondence: jut.wynne@nau.edu

'Department of Biological Sciences, Colorado Plateau Museum of Arthropod Biodiversity, Northern Arizona University (NAU), Flagstaff, USA

${ }^{3}$ Center for Adaptable Western Landscapes, NAU, Flagstaff, USA

Full list of author information is available at the end of the article
}

were prohibited [10]). In 2017, with support from the Rapanui people, the Chilean government ultimately declared the remaining $74 \%$ of the $579,368 \mathrm{~km}^{2}$ aquatic territory as protected [11]. Today, this region represents the largest marine protected area in South American waters [2] and one of the largest in the world.

Regarding our knowledge of terrestrial arthropods on the island, only one species, Cryptamorpha desjardinsii (Guérin-Méneville, 1844) (Coleoptera: Silvabidae) was previously documented on the island [7]. In 2012, arthropods were collected during the Ministry of Agriculture's National Forest Corporation's (CONAF) annual bird monitoring survey; researchers collected specimens belonging to the orders Coleoptera, Lepidoptera, Diptera, and Araneae [6]. Unfortunately, no additional information was available on this survey.

In 2016, the second author (S.Y. Pakarati) and another researcher collected terrestrial arthropods on Salas y Gómez island during CONAF's annual bird monitoring survey. Here we present the findings of that work, which represent the most comprehensive arthropod inventory to date. Based upon our findings, we also provide recommendations for future research and management.

(c) The Author(s). 2020 Open Access This article is licensed under a Creative Commons Attribution 4.0 International License, which permits use, sharing, adaptation, distribution and reproduction in any medium or format, as long as you give appropriate credit to the original author(s) and the source, provide a link to the Creative Commons licence, and indicate if changes were made. The images or other third party material in this article are included in the article's Creative Commons licence, unless indicated otherwise in a credit line to the material. If material is not included in the article's Creative Commons licence and your intended use is not permitted by statutory regulation or exceeds the permitted use, you will need to obtain permission directly from the copyright holder. To view a copy of this licence, visit http://creativecommons.org/licenses/by/4.0/. 


\section{Methods}

\section{Study area}

Motu Motiro Hiva Marine Park (the marine park surrounding Salas y Gómez island) is one of the most remote and pristine protected areas of the South Pacific [12]. Often considered the easternmost extent of the Polynesian triangle (e.g., [13]), Salas y Gómez occurs within the Chilean province of Easter Island and is grouped with the surrounding small islands to form the East Island Ecoregion (EIE) [14].

Salas y Gómez is a volcanic island, which rose $\sim 3500 \mathrm{~m}$ from the ocean floor around two million years ago $[1,2]$. Approximately $3300 \mathrm{~km}$ from mainland Chile, $402 \mathrm{~km}$ northeast of Rapa Nui (Easter Island), and $2600 \mathrm{~km}$ from the Juan Fernandez Islands, this small, isolated island is uninhabited by humans [3]. Low, relatively flat, and horseshoe-shaped, Salas y Gómez encompasses an area of $2.5 \mathrm{~km}^{2}$. Highest elevations occur at the eastern and western ends with the eastern extent reaching $\sim 30 \mathrm{~m}$ above sea level. The eastern and western extents of the island are linked by a low-lying isthmus subjected to flooding during storm events and a small sandy beach occurs along the northeastern shore. Salas y Gómez supports relatively low plant diversity consisting of three succulent species [5] and shore spleenwort (Asplenium obliquum Forst) [5, 15].

\section{Arthropod Sampling \& Analysis}

On August 23, 2016, the second author (S.Y. Pakarati) and Edgardo Quezada (Servicio Agricola y Ganadero [SAG], Valparaíso Region, Rapa Nui Office) collected arthropods. As the primary objective of this expedition was the annual bird monitoring surveys conducted by
CONAF, search time was limited. Within each of the two areas sampled (Fig. 1), two observers searched for arthropods for approximately $30 \mathrm{~min}$ by examining vegetation, the soil, and underneath rocks (totaling 2 person hours of searching).

Arthropods were hand-collected with forceps and watercolor paintbrushes and then placed directly into vials with 95\% ethanol. Specimens were examined and photographed at the Colorado Plateau Museum of Arthropod Biodiversity, Department of Biological Sciences, Northern Arizona University. All specimens will ultimately be deposited at the Museo Nacional de Historia Natural in Santiago, Chile.

\section{Results}

Forty-six specimens across 15 morphospecies representing 10 taxonomic orders were collected (Table 1, Figs. 2, 3 and 4). Lepidoptera represented the highest species diversity $(n=3)$, while terrestrial isopods were most abundant (nine individuals). Low-level taxonomic identifications include a morphospecies of Segestriidae (Araneae), Garypus sp. (Pseudoscorpiones: Garypidae), Atheta sp. (Coleoptera: Staphylinidae), Entomobrya atrocincta Schott, 1896 (Entomobryomorpha: Entomobryidae), Lynchia americana Leach, 1817 (Diptera: Hippoboscidae), and a morphospecies of Trogiidae (Psocoptera). Total number of morphospecies per taxonomic group are summarized (Fig. 2) and an annotated species list is provided (Table 1).

\section{Discussion}

While baseline in nature, this study represents the most detailed arthropod study of Salas y Gómez. At least 15

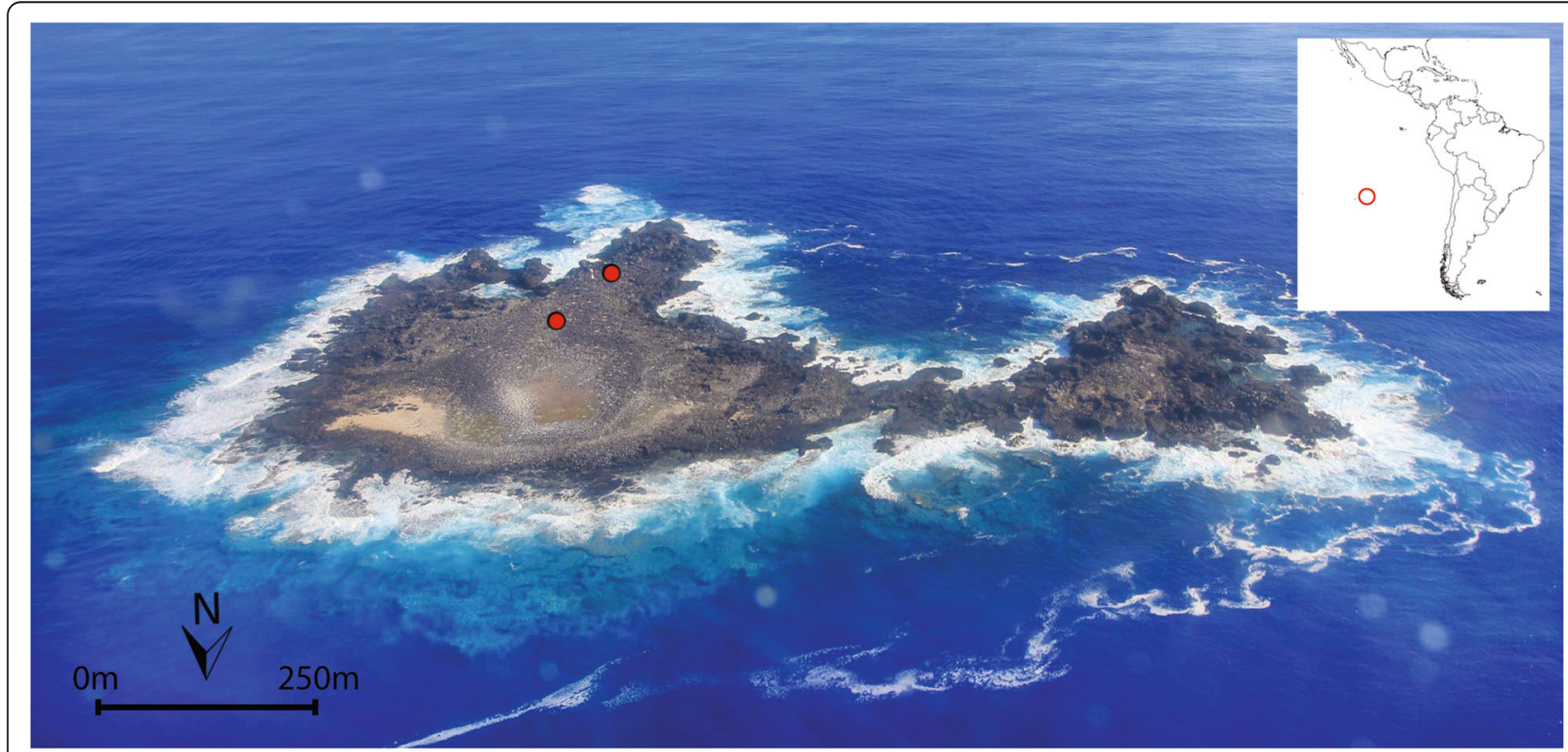

Fig. 1 Salas y Gómez island, Chile with the two sampling locations demarcated (red dots) 
Table 1 Annotated species list of the 15 morphospecies from Salas y Gómez island, Chile

\begin{tabular}{l} 
Arachnida: Araneae \\
Araneae sp. \\
Segestriidae \\
Segestriidae sp. \\
Pseudoscorpiones \\
Garypidae \\
Garypus sp. \\
Insecta \\
Collembola \\
Entomobryidae \\
Entomobrya atrocincta Schott, 1896 \\
Zygentoma \\
Zygentoma sp. \\
Hemiptera \\
Miridae sp. \\
Fulgoromorpha \\
Fulgoromorpha sp. \\
Psocoptera \\
Trogiidae \\
Trogiidae sp. \\
Coleoptera \\
Staphylinidae \\
Atheta sp. \\
Lepidoptera \\
Lepidoptera larva sp. 1 \\
Lepidoptera larva sp. 2 \\
Noctuidaidae sp. \\
\hline ididae? sp. 2 \\
\hline
\end{tabular}

morphospecies exist on this remote island. Of the 46 individuals collected, two morphospecies (E. atrocincta and $L$. americana) were identified to species level (Fig. 4). Additionally, the Segestriidae morphospecies (Fig. 3b) is being formally described as a new species (D. Cotoras, pers. comm. 2018). It is likely to be the first endemic arthropod species discovered on Salas y Gómez and may ultimately represent the first terrestrial species of management concern.

For the remaining 12 morphospecies, there were various obstacles in achieving higher taxonomic resolution. For the pseudoscorpion, we collected one tritonymph of

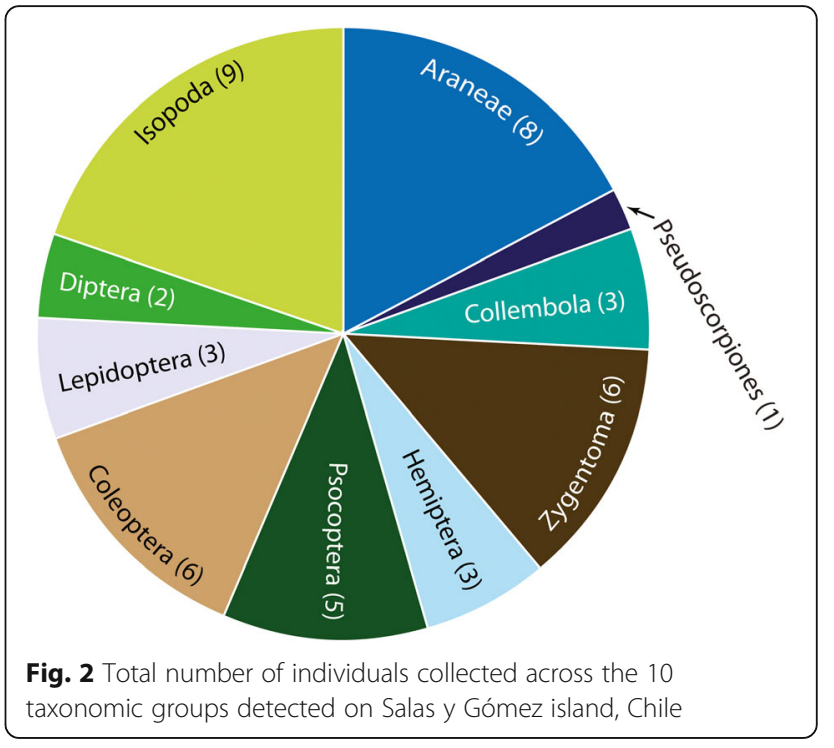

the genus Garypus (Fig. 3a). While this also likely represents a new and endemic species (M. Harvey, pers. comm., 2019), examination of adult characters is required to properly identify arachnids to species level. To both confirm whether this is a new endemic species and to formally describe it, we will require additional specimens (i.e., multiple adult males and females). The Staphylinid beetle, Atheta sp. (Fig. 3d), cannot be identified beyond the genus level because Chilean Aleocharinae are presently unidentifiable. Original descriptions of congeners are insufficient to reliably identify the specimen, and aside from a few select genera, no one is actively working on this group (V. Assing, pers. comm. 2019). Regarding the two terrestrial isopod morphospecies (Halophilosciidae? sp. 1 and 2), we suggest these two isopod morphospecies may belong to the genus Littorophiloscia (S. Taiti, pers. com. 2020); however, these specimens will require examination by an isopod systematist to confirm.

As would be expected, avian species richness (i.e., total number of species) increased as additional surveys (i.e., when more time was allocated) were conducted $[4-6,12]$. Schlatter [12] reported six species based upon brief site visits by naturalists; unfortunately, no survey methods were presented. Today, 16 seabird species are known from the island [6]. The arthropod inventory results presented here were similarly constrained by time. Because the primary objective of the 2016 work was to census seabirds, observers spent only two person hours collecting arthropods. Through this abbreviated effort, at least 15 morphospecies were identified, which stands as a testament to the significance of continuing this work. Importantly, we identified several research questions that should be addressed to best guide future conservation and management efforts.

First, what options exist for expanding this inventory work and/ or developing future arthropod monitoring 


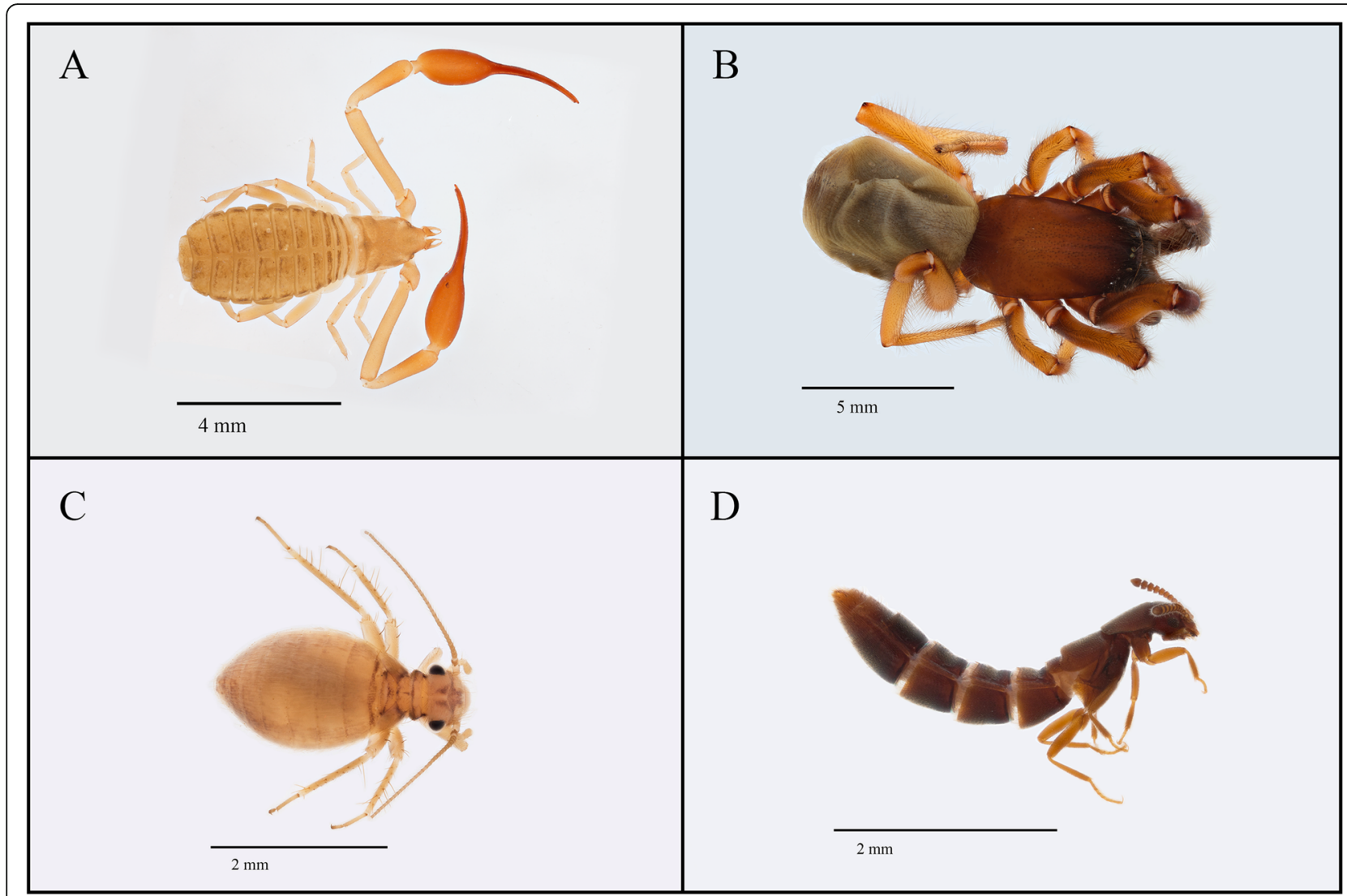

Fig. 3 a Garypus sp., b Segestriidae morphospecies, c Trogiidae morphospecies, and d Atheta sp. from Salas y Gómez island, Chile

strategies for Salas y Gómez island? To best capture diversity and identify potential management concern species, a multi-day sampling frame, which employ multiple techniques, is highly recommended. This could be accomplished by focusing future efforts on examining the different habitat types. Harrison and Jehl [4] identified at least five different topographic features on the island (which may serve as a proxy for different habitats); these include (1) the eastern half of the island, which is relatively uniform and flat; (2) a sandy beach on the northeastern extent of the island; (3) steep-sided rocky cliffs to the south rising to $\sim 10 \mathrm{~m}$ elevation; (4) a sandy depression approximately $70 \mathrm{~m}$ in diameter in the west-central section of the island; and, (5) the more rocky western half of the island. We have identified a sixth area, pelagic bird nesting areas, which could reveal

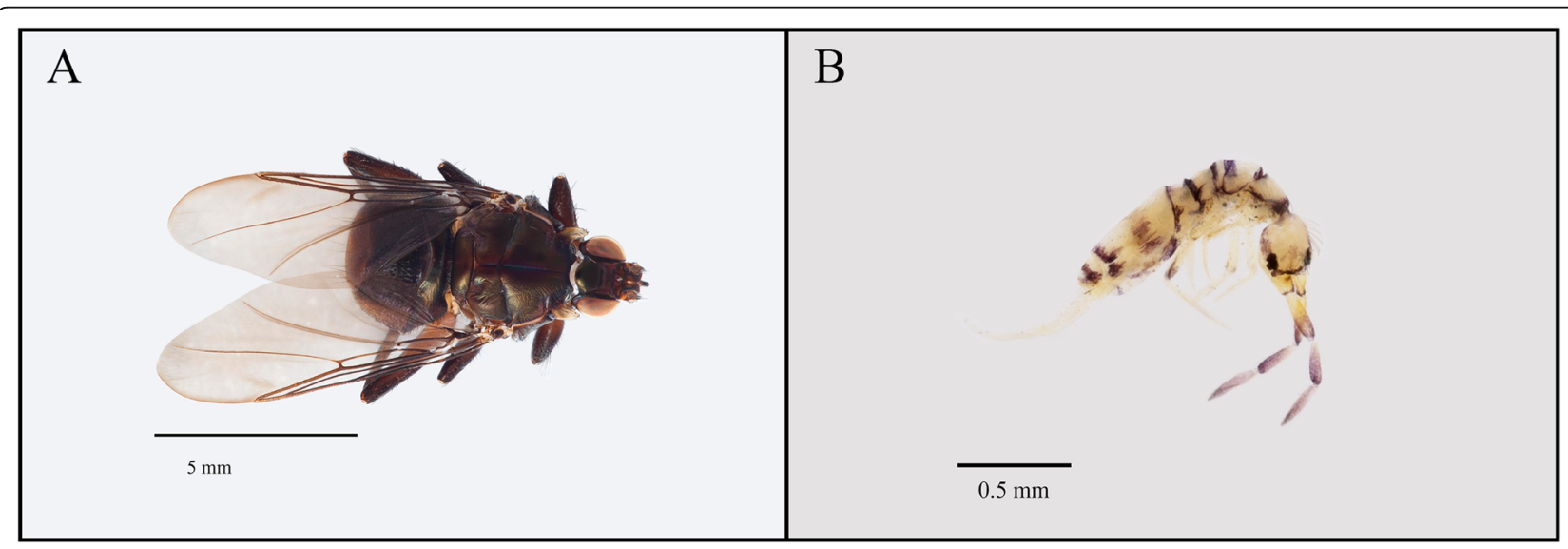

Fig. 4 a Lynchia americana Leach, 1817, and b Entomobrya atrocincta Schott, 1896 (\%), from Salas y Gómez island, Chile 
unique taxa. Each of these sites likely supports different species. Sampling techniques to consider include conducting timed searches within $1 \mathrm{~m}^{2}$ quadrats and surface pitfall trapping similar to previous work on Rapa Nui [16], which would maximize our ability to best capture diversity, provide a robust sampling frame, and establish a framework for future monitoring efforts. These sampling locations could be marked and revisited should monitoring be required. Alternatively, if an intensive effort cannot be supported in the near future, we recommend CONAF Rapa Nui personnel continue sampling arthropods during their annual pelagic bird censuses. Sampling arthropods annually would require a diminutive time investment for CONAF (i.e., an additional 1 to $2 \mathrm{~h}$ per visit to search for and collect arthropods). Elements of the above mentioned sampling design could be incorporated whereby researchers establish a systematic framework for sampling the different habitat types during each visit. Both of these repeatable approaches and the derived data may ultimately be modified to monitor endemic and/or indicator species.

The prevalence of Cryptamorpha desjardinsii should be further examined and potentially monitored by CONAF and SAG. Native to "tropical Asia" [17], this nonnative species is predaceous in its larval stage [18]. As virtually nothing is known concerning the entomofauna of Salas y Gómez island, it is unknown whether this species is competing with and/or predating upon endemic arthropod populations.

Additionally, understanding the relationship between pelagic birds and arthropods could both improve monitoring of avian populations, as well as shed additional light on bird-arthropod phoresy in the South Pacific. Pseudoscorpions have been widely documented using birds for dispersal [19-21]. Because nothing is known about pelagic bird phoresy in this part of the South Pacific Ocean, it is possible Garypus sp. (a potentially undescribed species) arrived to Salas y Gómez island via this method. Currently, no pseudoscorpions have been identified on Rapa Nui [22-24]. We suggest conducting arthropod surveys (to search for pseudoscorpions) on Motu Nui (a small islet off the southwestern coast) and Rano Raraku crater, the two primary pelagic bird rookeries of Rapa Nui. If present on both islands, this could launch an exciting investigation into another ecological connection between these two geographical regions.

This study represents the small first step toward characterizing the arthropod community of Salas y Gómez. Although Motu Motiro Hiva Marine Park is a protected area, little is known regarding the natural history of the terrestrial fauna - with the exception of avian species. As it is infeasible to manage what is unknown, a future management plan will benefit from a baseline understanding of the terrestrial flora and fauna on the island.
We hope this project will serve to inspire future workers to expand upon our efforts and acquire the data necessary to most effectively manage the island's terrestrial ecosystem. Through such an initiative, researchers will both collect the information necessary to characterize the natural history, as well as contribute to the protection of sensitive natural resources on Salas y Gómez island.

\section{Conclusion}

Two person hours spent sampling two locations in southeastern Salas y Gómez resulted in the identification of at least 15 morphospecies. Albeit brief, these surveys underscore the potential for additional work to better characterize the arthropod communities, as well as identify potential management concern species. Importantly, we are hopeful this project will engender future research on Salas y Gómez island. Given the paucity of information on the terrestrial communities of Salas y Gómez, additional research will be required to: (1) examine the potential ecological relationships between Salas y Gómez and other neighboring islands; (2) characterize potential dispersal mechanisms between Salas y Gómez and neighboring islands; and, (3) acquire the data necessary to develop effective policies to best manage terrestrial island habitats.

\section{Abbreviations \\ CONAF: Ministry of Agriculture's National Forest Corporation; EIE: East Island Ecoregion}

\section{Acknowledgements}

The second author (S.Y. Pakarati) would like to thank the following for making this research possible: Edgardo Quezada V. from Servicio Agricola y Ganadero (SAG), Oficina de Rapa Nui; Pedro Lazo Hucke with CONAF, Rapa Nui; Violeta Producciones of Rapa Nui; the Chilean Navy and the AP 41 Aquiles crew; and Consejo Asesor de Monumentos Nacionales (CAMN) and Secretaria Tecnica de Patrimonio (STP) in Rapa Nui. Aaron Smith and Chris Wirth assisted the lead author with imaging arthropod specimens. Ryan Lumen provided comments leading to the improvement of this paper. Lab technician, Anna Ross, as well as systematists Volker Assing (Staphylinidae), Darko Cotoras (Araneae), Mark Harvey (Pseudoscorpiones), Frans Jassens (Collembola), Edward Mockford (Psocoptera), and Stefano Taiti (Isopoda) assisted with arthropod identifications. Frank Howarth provided useful discussions on Lepidoptera taxonomy. Justine Baca provided Fig. 2.

\section{Authors' contributions}

Specimen collection: SYP. Specimen processing and analysis: SNH, JJW. Manuscript preparation: SNH, JJW, SYP. All authors read and approved the final version of the manuscript.

\section{Funding}

None.

Availability of data and materials

Specimens will ultimately be deposited at the Museo Nacional de Historia Natural, Santiago, Chile.

Ethics approval and consent to participate Not applicable.

Consent for publication

Not applicable.

Competing interests

The authors have no competing interests. 


\section{Author details}

${ }^{1}$ Department of Biological Sciences, Colorado Plateau Museum of Arthropod Biodiversity, Northern Arizona University (NAU), Flagstaff, USA. ${ }^{2}$ Consejo Asesor de Monumentos Nacionales de Chile - Rapa Nui, Manu Project, Rapa Nui, and Laboratorio de Socioecosistemas, Departamento de Ecología, Universidad Autónoma de Madrid, Madrid, Spain. ${ }^{3}$ Center for Adaptable Western Landscapes, NAU, Flagstaff, USA.

Received: 6 January 2020 Accepted: 20 May 2020

Published online: 02 June 2020

\section{References}

1. Newman WA, Foster BA. The Rapanuian faunal district (Easter and Sala y Gòmez): in search of ancient archipelagos. Bull Mar Sci. 1983;33:633-44.

2. Friedlander AM, Ballesteros E, Beets J, Berkenpas E, Gaymer CF, Gorny M, Sala E. Effects of isolation and fishing on the marine ecosystems of Easter Island and Salas y Gómez. Chile Aquat Conserv. 2013;23:515-31.

3. Flores MA, Schlatter RP, Hucke-Gaete R. Seabirds of Easter Island, Salas y Gómez Island and Desventuradas Islands, southeastern Pacific Ocean. Lat Am J Aquat Res. 2014;42:752-9.

4. Harrison P, Jehl JR Jr. Notes on the seabirds of Sala y Gómez. Condor. 1988; 90:259-61.

5. Vilina YA, Gazitua FJ. The birds of Sala y Gómez Island, Chile. Waterbirds. 1999;22:459-62.

6. Hucke PL. El mas extenso patrullaje y monitoreo del SNASPE. Chile Forestal. 2014:36-9. https://www.conaf.cl/wp-content/files_mf/140684113 8páginaGUARDAPARQUEPEDROLAZOjulio.pdf.

7. Elgueta M, Lazo PH. Cryptamorpha desjardinsi (Guérin-Méneville, 1844) primer registro de un insecto (Coleoptera: Silvabidae) para la Isla Salas y Gómez, Chile. Acta Entomológica Chilena. 2013;33:63-6.

8. [DORC] Diario Oficial de la República de Chile. 1976. Declaranse Santuarios de la Naturaleza la Isla Sala y Gómez e islotes adyacentes a Isla de Pascua, Decreto Supremo №556, art. $8^{\circ}$. Ministerio de Educación, Santiago.

9. Toonen RJ. One size does not fit all: the emerging frontier in large-scale marine conservation. Mar Pollut Bull. 2013;77:7-10.

10. DORC. Declara Parque Marino Motu Motiro Hiva, Decreto Supremo $N^{\circ} 235$ Santiago: Ministerio de Economía Fomento y Turismo Subsecretaria de Pesca; 2010

11. DORC. Crea Área Marina Costera Protegida de Múltiples Usos Rapa Nui, Decreto Supremo № 10. Santiago: Ministerio del Medio Ambiente; 2018.

12. Schlatter RP. Conocimiento y situación de la ornitofauna en las islas oceánicas chilenas. In: Castilla JC, editor. Islas oceánicas chilenas: conocimiento científico y necesidades de investigaciones. Santiago: Universidad Católica de Chile; 1987. p. 271-85.

13. Thibault JC, Cibois A. Birds of eastern Polynesia: a biogeographic atlas. Barcelona, Spain: Lynx Edicions; 2017. p. 440.

14. Easton EE, Sellanes J, Gaymer CF, Morales N, Gorny M, Berkenpas E. Diversity of deep-sea fishes of the Easter Island Ecoregion. Deep Sea Res Part II Top Stud Oceanogr. 2017;137:78-88.

15. Skottsberg $C$. The natural history of Juan Fernandez and Easter Islands, vol. 1. Uppsala: Almquist \& Wiksells Boktryckeri; 1956. p. 438.

16. Wynne JJ, Bernard EC, Howarth FG, Sommer S, Soto-Adames FN, Taiti S, Mockford EL, Horrocks M, Pakarati L, Pakarati-Hotus V. Disturbance relicts in a rapidly changing world: the Rapa Nui (Easter Island) factor. BioScience. 2014;64:711-8

17. Arnett RH Jr, Thomas MC, Skelley PE, Frank JH. American Beetles, Vol. II, Polyphaga: Scarabaeoidea through Curculionoidea. England: CRC Press; 2017. p. 861.

18. Thomas M. 1993. The flat bark beetles of Florida (Coleoptera: Silvanidae, Passandridae, Laemophloeidae). In: arthropods of Florida and neighboring land areas, Florida Dept. Agric. Consum. Serv. Contribution 789:1-101.

19. Morton B, Britton JC, Martins MF. The Lajes do Pico marsh: a case for coastal conservation in the Açores. Açoreana. 1996;8:183-200.

20. Poinar GO Jr, Curcic BP, Cokendolpher JC. Arthropod phoresy involving pseudoscorpions in the past and present. Acta arach. 1998:47:79-96.

21. Turienzo P, Di lorio O, Mahnert V. Global checklist of pseudoscorpions (Arachnida) found in birds' nests. Rev Suisse Zoo. 2010;117:557-98.

22. Olalquiaga G. Anotaciones entomológicas: Insectos y otros artrópodos colectados en Isla de Pascua. Agricultura Técnica. 1946;7:231-3.

23. Wynne JJ, Ika F, Yancovic Pakarati S, Gonzales L, Hucke PL, Manuheuroroa S, Pakarati L, Bristow D, Rodríguez Brizuela R, Fies E, Glover N, Hicks WL, Kisner
D, Marinakis I, Shipley B, Yeager B, Villagra C, Tucki E, Scherson R. Islandwide inventory for endemic ground-dwelling arthropods in extreme environments of Rapa Nui, Explorers Club flag report flag \# 139. New York: Explorers Club; 2016. p. 28.

24. Wynne JJ, Sommer S, Howarth FG, Dickson BG, Voyles KD. Capturing arthropod diversity in complex cave systems. Divers Distrib. 2018;24: 1478-91.

\section{Publisher's Note}

Springer Nature remains neutral with regard to jurisdictional claims in published maps and institutional affiliations.

\section{Ready to submit your research? Choose BMC and benefit from:}

- fast, convenient online submission

- thorough peer review by experienced researchers in your field

- rapid publication on acceptance

- support for research data, including large and complex data types

- gold Open Access which fosters wider collaboration and increased citations

- maximum visibility for your research: over $100 \mathrm{M}$ website views per year

At BMC, research is always in progress.

Learn more biomedcentral.com/submissions 